\title{
Ten genetic polymorphisms in bladder cancer
}

\author{
RAYMOND A CARTWRIGHT*, RAFID ADIB $\dagger$, IAN APPLEYARD $\ddagger$, \\ JOHN G COXON §, ROBIN W GLASHAN\|, BRIAN RICHARDS $ף$, \\ MEL R G ROBINSON**, ERIC SUNDERLAND $\dagger \dagger$, AND DENISE BARHAM-HALL $+{ }_{++}^{+}$
}

From *the Yorkshire Regional Cancer Organisation, Cookridge Hospital, Leeds; †Clayton and Pinderfields Hospitals, Wakefield; $\ddagger$ Airedale General Hospital, Steeton, Keighley; §Halifax General Hospital, Halifax; ||Huddersfield Royal Infirmary, Huddersfield; \York District General Hospital, York; **Pontefract General Hospital, Southgate, Pontefract; ††Department of Anthropology, University of Durham, South Road, Durham; and $\ddagger \ddagger$ Department of Community Medicine and General Practice, University of Leeds, Hyde Terrace, Leeds.

SUMMARY Data are presented on a group of cases of primary carcinoma of the bladder, detailing red cell surface blood group antigenic phenotypes, serum haptoglobin phenotypes, and some red cell isoenzyme phenotypes. Account is taken of the stage of the disease at presentation. The results are compared with corresponding phenotype frequencies in groups of presumed healthy persons originating either in Yorkshire or County Durham. Differences in relative incidences were found in the haptoglobin, phosphoglucomutase (PGM), and some other systems. These are both differences between all cases and controls and between particular stages at presentation and controls.

Various studies have been published since 1956 which investigate the relationship between the ABO and a few other blood group systems and bladder cancer. ${ }^{1-11}$ Some of these results are summarised by Mourant $e t$ al $^{12}$ and indicate an excess of the $\mathrm{A}$ gene of the ABO blood group system among bladder cancer cases.

Many of these studies might be criticised, however, on the grounds that they only examine a few genetic polymorphisms. One study includes esterase D subtypes $^{13}$ and other reports exist which report on two other blood group systems. ${ }^{12}$ This paper reports a series of bladder cancer cases from Yorkshire whose ABO, Rhesus, and MNSs results have been reported elsewhere, ${ }^{14}$ giving information on ten further genetic polymorphisms.

\section{Method}

Patients with transitional cell carcinoma of the urothelium (ICD 9th edition 188 and 233.3) include cases previously described as 'papilloma' as well as 'carcinoma'. They are, with the exception of some patients from York and Huddersfield, all newly diagnosed (incident) cases of bladder cancer arising in six Yorkshire hospitals from October 1978 to October 1981. The other (prevalent) cases were diagnosed some time before. They have all been Received for publication 15 September 1982. involved in an epidemiological study of bladder cancer in West Yorkshire, some results of which have been reported elsewhere. ${ }^{1516}$ The entire group is being carefully followed and the disease stage at presentation is known for the majority of patients. The staging is the result of both clinical and histopathological examination and follows the TNM system for bladder cancer ${ }^{17}$ as follows:

Tis, pre-invasive flat carcinoma or carcinoma in situ. T1, freely mobile mass which does not invade beyond the lamina propria (this includes $\mathrm{Ta}$ ).

$\mathrm{T} 2$, induration of the bladder wall and superficial muscle invasion.

$\mathrm{T} 3$, induration or mobile mass palpable after resection and deep muscle invasion.

T4, tumour fixed to pelvis or extending to neighbouring structures.

Blood was collected from cases and sent to Durham University by post for analysis, usually arriving within 24 hours of venepuncture. Analysis of the red cell surface antigens took place using standard methods of agglutination, the exact technique depending on the nature of each antiserum. Serum was separated and electrophoresis on starch gels undertaken for haptoglobin variation after the method of Harris et al. ${ }^{18}$ Red cell haemolysates were prepared, and electrophoresis for the following polymorphisms undertaken, broadly 
following the techniques of the various authors quoted: phosphoglucomutase (PGM) ${ }^{19}$ acid phosphatase (AP) ${ }^{20}$ adenylate kinase (AK), ${ }^{21}$ esterase $\mathrm{D}$ (EsD), ${ }^{13}$ and adenosine deaminase (ADA). ${ }^{22}$

The comparison groups are all from the laboratory which tested the cases and represent control series built up from various normal populations in County Durham. They are detailed by Williams ${ }^{23}$ and, in general, represent adults aged 25 to 65 years of age.

The results were recorded and gene frequencies analysed by gene counting or the use of the homozygous recessive frequency, depending on the polymorphic system.

Relative incidence was computed using the basic method of Woolf, ${ }^{24}$ but also computing the MantelHaenszel chi statistic ${ }^{25}$ and confidence limits, after the method of Miettinen. ${ }^{26}$

\section{Results}

Table 1 indicates the number and sources of the bladder cancer cases used in this study. Not all results are available for each system and a few cases were at an indeterminate stage at diagnosis, so the numbers recorded in the subsequent tables are often fewer than this total.

The results by sex for the blood groups, serum haptoglobin, and red cell isoenzyme types have been computed, but as there are no statistical differences between the sexes for any system all subsequent results have the sexes pooled.

Table 2 gives the results of the phenotype determinations and the corresponding gene frequencies compared with those of the various corresponding Durham control series. The gene frequencies are presented together with a standard error of frequency.

Table 3 gives the relative incidence between case and control phenotypes along with the confidence limits and probability levels. The probability column indicates that there is an excess of the $B$ acid phosphatase phenotype when contrasted with the $A$ and BA types and that there are more 21 and 22 phenotypes in the phosphoglucomutase and adenosine deaminase systems. These latter two

TABLE 1 Yorkshire bladder cancer: sources of cases.

\begin{tabular}{lc}
\hline Health districts & No of cases \\
\hline Airedale & 8 \\
Calderdale & 37 \\
Huddersfield & 143 \\
Pontefract & 26 \\
Wakefield & 34 \\
York & 40 \\
Total & 288 \\
\hline
\end{tabular}

TABLE 2 Bladder cancer cases and controls: blood group phenotypes and gene frequencies.

\begin{tabular}{|c|c|c|c|c|c|}
\hline & & \multicolumn{2}{|l|}{ All cases } & \multicolumn{2}{|c|}{ Durham controls } \\
\hline & & No & $\%$ & No & $\%$ \\
\hline \multicolumn{6}{|l|}{ Kidd } \\
\hline \multirow[t]{4}{*}{ Phenotypes } & aa & 17 & $32 \cdot 1$ & 7 & $25 \cdot 9$ \\
\hline & $a b$ & 19 & $35 \cdot 8$ & 13 & $48 \cdot 1$ \\
\hline & bb & 17 & $32 \cdot 1$ & 7 & $25 \cdot 9$ \\
\hline & Total & 53 & & 27 & \\
\hline \multirow[t]{2}{*}{ Genes } & a & 0.5002 & \pm 0.0687 & 0.4995 & \pm 0.0962 \\
\hline & $\mathrm{b}$ & 0.4998 & & $0 \cdot 5005$ & \\
\hline \multicolumn{6}{|l|}{ Duffy } \\
\hline \multirow[t]{4}{*}{ Phenotypes } & aa & 54 & 188 & 55 & $19 \cdot 0$ \\
\hline & $a b$ & 140 & $48 \cdot 8$ & 126 & $43 \cdot 6$ \\
\hline & $\mathrm{bb}$ & 93 & $32 \cdot 4$ & 108 & $37 \cdot 4$ \\
\hline & Total & 287 & & 289 & \\
\hline \multirow[t]{2}{*}{ Genes } & a & 0.4320 & \pm 0.0292 & 0.4080 & \pm 0.0289 \\
\hline & $\mathrm{b}$ & 0.5680 & & 0.5920 & \\
\hline \multicolumn{6}{|l|}{ Kell } \\
\hline Phenotypes & KK & 1 & $0 \cdot 3$ & 1 & $0 \cdot 2$ \\
\hline & Kk & 25 & $8 \cdot 7$ & 34 & $6 \cdot 6$ \\
\hline & kk & 262 & $91 \cdot 0$ & 479 & $93 \cdot 2$ \\
\hline & Total & 288 & & 514 & \\
\hline Genes & $\mathrm{K}$ & 0.0465 & \pm 0.0124 & 0.0350 & \pm 0.0081 \\
\hline & $\mathrm{k}$ & 0.9535 & & 0.9650 & \\
\hline Penney & & & & & \\
\hline Phenotypes & aa & 0 & 一 & 0 & $\rightarrow$ \\
\hline & $a b$ & 3 & $1 \cdot 5$ & 6 & $1 \cdot 4$ \\
\hline & $\mathrm{bb}$ & 191 & $98 \cdot 5$ & 417 & $98 \cdot 6$ \\
\hline & Total & 194 & & 423 & \\
\hline Genes & a & 0.0075 & \pm 0.0062 & 0.0070 & \pm 0.0041 \\
\hline & $\mathrm{b}$ & 0.9925 & & 0.9930 & \\
\hline Haptoglobin & & & & & \\
\hline Phenotypes & $1-1$ & 51 & $18 \cdot 8$ & 16 & $18 \cdot 6$ \\
\hline & $2-1$ & 117 & $43 \cdot 2$ & 44 & $51 \cdot 2$ \\
\hline & $2-2$ & 103 & $38 \cdot 0$ & 26 & $30 \cdot 2$ \\
\hline & Total & 271 & & 86 & \\
\hline Genes & 1 & 0.4040 & \pm 0.0298 & 0.4420 & \pm 0.0536 \\
\hline (ט) & 2 & 0.5960 & & 0.5580 & \\
\hline Acid phosphat & & & & & \\
\hline Phenotypes & A & 27 & $9 \cdot 3$ & 24 & $10 \cdot 5$ \\
\hline & BA & 115 & $39 \cdot 7$ & 111 & $48 \cdot 5$ \\
\hline & B & 122 & $42 \cdot 1$ & 80 & $34 \cdot 9$ \\
\hline & BC & 14 & $4 \cdot 8$ & 10 & $4 \cdot 4$ \\
\hline & CA & 12 & $4 \cdot 1$ & 4 & $1 \cdot 7$ \\
\hline & Total & 290 & & 229 & \\
\hline Genes & a & 0.3120 & \pm 0.0272 & $0 \cdot 3560$ & \pm 0.0316 \\
\hline & b & 0.6435 & & 0.6135 & \\
\hline & c & 0.0445 & & 0.0305 & \\
\hline Phosphoglucor & hutase & & & & \\
\hline Phenotypes & $1-1$ & 158 & $59 \cdot 0$ & 79 & $68 \cdot 7$ \\
\hline & $2-1$ & 95 & $35 \cdot 4$ & 32 & $27 \cdot 8$ \\
\hline & $2-2$ & 15 & $5 \cdot 6$ & 4 & $3 \cdot 5$ \\
\hline & Total & 268 & & 115 & \\
\hline Genes & 1 & 0.7670 & \pm 0.0259 & 0.8260 & \pm 0.0354 \\
\hline & 2 & $0 \cdot 2330$ & & $0 \cdot 1740$ & \\
\hline Adenylate kina & & & & & \\
\hline Phenotypes & $1-1$ & 256 & $91 \cdot 8$ & 363 & $91 \cdot 9$ \\
\hline & $2-1$ & 21 & $8 \cdot 2$ & 30 & $7 \cdot 6$ \\
\hline & $2-2$ & 0 & - & 2 & $0 \cdot 5$ \\
\hline & Total & 277 & & 395 & \\
\hline Genes & 1 & 0.9590 & \pm 0.0119 & 0.9570 & \pm 0.0102 \\
\hline & 2 & 0.0410 & & 0.0430 & \\
\hline Esterase D & & & & & \\
\hline Phenotypes & $1-1$ & 227 & $81 \cdot 9$ & 304 & $77 \cdot 9$ \\
\hline & $2-1$ & 48 & $17 \cdot 3$ & 82 & $21 \cdot 0$ \\
\hline & $2-2$ & 2 & 0.7 & 4 & $1 \cdot 0$ \\
\hline & Total & 277 & & 390 & \\
\hline Genes & 1 & 0.9055 & \pm 0.0176 & 0.8850 & \pm 0.0162 \\
\hline & 2 & 0.0945 & & $0 \cdot 1150$ & \\
\hline Adenosine dea & ninase & & & & \\
\hline Phenotypes & $1-1$ & 240 & $87 \cdot 9$ & 96 & $94 \cdot 1$ \\
\hline & $2-1$ & 32 & $11 \cdot 7$ & 6 & $5 \cdot 9$ \\
\hline & $2-2$ & 1 & 0.4 & - & 一 \\
\hline & Total & 273 & & 102 & \\
\hline Genes & 1 & 0.9375 & \pm 0.0146 & 0.9705 & \pm 0.0168 \\
\hline & 2 & 0.0625 & & 0.0295 & \\
\hline
\end{tabular}


TABLE 3 Relative incidence of bladder cancer phenotypes when compared with control phenotypes.

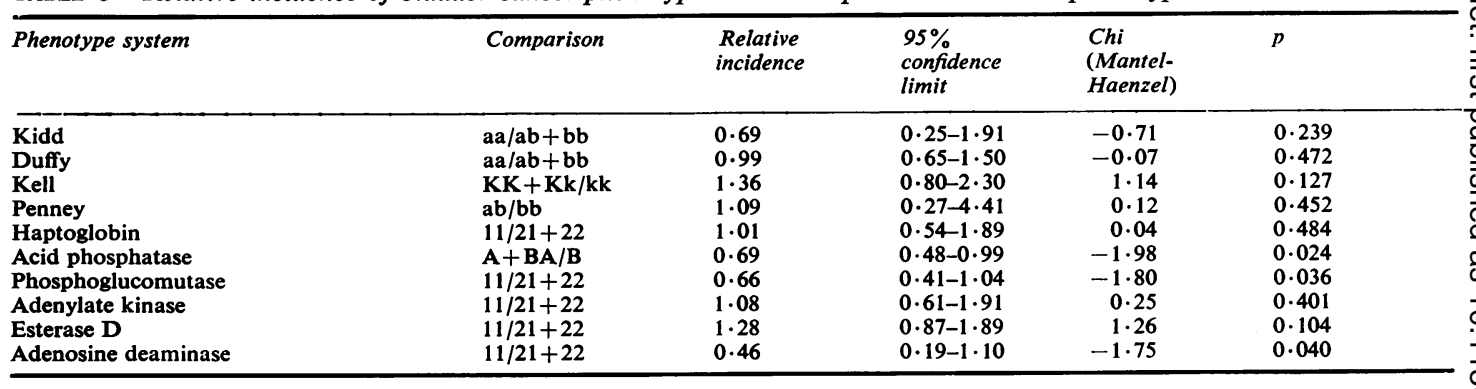

TABLE 4 Blood group haptoglobin and isoenzyme phenotypes and stage at presentation (sexes pooled).

\begin{tabular}{rllllll}
\hline Phenotypes & $T 1$ & T2 & T3 & T4 & Carcinoma \\
No $\%$ & No $\%$ & No $\%$ & No $\%$ & $\begin{array}{l}\text { in situ } \\
\text { No } \%\end{array}$ \\
& & & & &
\end{tabular}

\begin{tabular}{|c|c|c|c|c|c|c|c|c|c|c|}
\hline \multicolumn{11}{|l|}{ Duffy } \\
\hline $\mathbf{a a}$ & 28 & $16 \cdot 9$ & 10 & $22 \cdot 2$ & 10 & $23 \cdot 3$ & 1 & $16 \cdot 7$ & 2 & $16 \cdot 7$ \\
\hline ab & 85 & $51 \cdot 2$ & 23 & $51 \cdot 1$ & 19 & $44 \cdot 2$ & 2 & $33 \cdot 3$ & 7 & $58 \cdot 3$ \\
\hline bb & 53 & $31 \cdot 9$ & 12 & $26 \cdot 7$ & 14 & $32 \cdot 6$ & 3 & $50 \cdot 0$ & 3 & $25 \cdot 0$ \\
\hline Total & 166 & & 45 & & 43 & & 6 & & 12 & \\
\hline \multicolumn{11}{|l|}{ Kell } \\
\hline KK & 1 & $0 \cdot 6$ & $\mathbf{0}$ & - & $\mathbf{0}$ & - & $\mathbf{0}$ & - & $\mathbf{0}$ & - \\
\hline Kk & 13 & $7 \cdot 8$ & 2 & 4.4 & 5 & $11 \cdot 6$ & 1 & $16 \cdot 7$ & 2 & $16 \cdot 7$ \\
\hline kk & 153 & $91 \cdot 6$ & 43 & $95 \cdot 6$ & 38 & $88 \cdot 4$ & 5 & $83 \cdot 3$ & 10 & $83 \cdot 3$ \\
\hline Total & 167 & & 45 & & 43 & & 6 & & 12 & \\
\hline \multicolumn{11}{|c|}{ Haptoglobin } \\
\hline $1-1$ & 32 & $20 \cdot 4$ & 2 & $5 \cdot 0$ & 10 & $23 \cdot 3$ & 2 & $40 \cdot 0$ & 3 & $27 \cdot 3$ \\
\hline $2-1$ & 64 & $40 \cdot 8$ & 23 & $57 \cdot 5$ & 18 & $41 \cdot 9$ & 2 & $40 \cdot 0$ & 6 & $54 \cdot 5$ \\
\hline $2-2$ & 61 & $38 \cdot 8$ & 15 & $37 \cdot 5$ & 15 & $34 \cdot 9$ & 1 & $20 \cdot 0$ & 2 & $18 \cdot 2$ \\
\hline Total & 157 & & 40 & & 43 & & 5 & & 11 & \\
\hline \multicolumn{11}{|c|}{ Acid phosphatase } \\
\hline A & 16 & $9 \cdot 6$ & 6 & $13 \cdot 0$ & 4 & $9 \cdot 1$ & $\mathbf{0}$ & - & 1 & $8 \cdot 3$ \\
\hline BA & 63 & $37 \cdot 7$ & 18 & $39 \cdot 1$ & 17 & $38 \cdot 6$ & 3 & $50 \cdot 0$ & 4 & $33 \cdot 3$ \\
\hline B & 72 & $43 \cdot 1$ & 19 & $41 \cdot 3$ & 18 & $40 \cdot 9$ & 2 & $33 \cdot 3$ & 7 & $58 \cdot 3$ \\
\hline BC & 11 & $6 \cdot 6$ & 1 & $2 \cdot 2$ & 2 & $4 \cdot 5$ & $\mathbf{0}$ & - & $\mathbf{0}$ & - \\
\hline CA & 5 & $3 \cdot 0$ & 2 & $4 \cdot 3$ & 3 & $6 \cdot 8$ & 1 & $16 \cdot 7$ & 0 & - \\
\hline Total & 167 & & 46 & & 44 & & 6 & & 12 & \\
\hline \multicolumn{11}{|c|}{ Phosphoglucomutase } \\
\hline 1-1 & 84 & $56 \cdot 4$ & 22 & $52 \cdot 4$ & 32 & $72 \cdot 7$ & 3 & $50 \cdot 0$ & 6 & $50 \cdot 0$ \\
\hline $2-1$ & 58 & 38.9 & 17 & $40 \cdot 5$ & 10 & $22 \cdot 7$ & 3 & $50 \cdot 0$ & 4 & $33 \cdot 3$ \\
\hline $2-2$ & 7 & 4.7 & 3 & $7 \cdot 1$ & 2 & $4 \cdot 5$ & 0 & - & 2 & $16 \cdot 7$ \\
\hline Total & 149 & & 42 & & 44 & & 6 & & 12 & \\
\hline \multicolumn{11}{|c|}{ Adenylate kinase } \\
\hline $1-1$ & 149 & $94 \cdot 3$ & 38 & $90 \cdot 5$ & 39 & $88 \cdot 6$ & 5 & $83 \cdot 3$ & 11 & $91 \cdot 7$ \\
\hline $2-1$ & 9 & $5 \cdot 7$ & 4 & $9 \cdot 5$ & 5 & 11.4 & 1 & $16 \cdot 7$ & 1 & $8 \cdot 3$ \\
\hline $2-2$ & & - & 0 & - & 0 & - & $\mathbf{0}$ & 一 & 0 & - \\
\hline Total & 158 & & 42 & & 44 & & 6 & & 12 & \\
\hline \multicolumn{11}{|c|}{ Esterase D } \\
\hline $1-1$ & 129 & $81 \cdot 6$ & 32 & $76 \cdot 2$ & 42 & $95 \cdot 5$ & 5 & $83 \cdot 3$ & & $60 \cdot 7$ \\
\hline $2-1$ & 29 & $18 \cdot 4$ & 9 & $21 \cdot 4$ & 1 & $2 \cdot 3$ & 1 & $16 \cdot 7$ & 4 & $33 \cdot 3$ \\
\hline $2-2$ & & - & 1 & $2 \cdot 4$ & 1 & $2 \cdot 3$ & $\mathbf{0}$ & - & $\mathbf{0}$ & - \\
\hline Total & 158 & & 42 & & 44 & & 6 & & 12 & \\
\hline \multicolumn{11}{|c|}{ Adenosine deaminase } \\
\hline $1-1$ & 138 & $87 \cdot 9$ & 36 & $85 \cdot 7$ & 36 & $85 \cdot 7$ & 6 & $100 \cdot 0$ & 11 & $91 \cdot 7$ \\
\hline $2-1$ & 18 & $11 \cdot 5$ & 6 & $14 \cdot 3$ & 6 & $14 \cdot 3$ & 0 & - & 1 & $8 \cdot 3$ \\
\hline $2-2$ & 1 & 0.6 & $\mathbf{0}$ & - & $\mathbf{0}$ & - & $\mathbf{0}$ & - & $\mathbf{0}$ & 一 \\
\hline Total & 157 & & 42 & & 42 & & 6 & & 12 & \\
\hline
\end{tabular}

results are quite weak, however, and the $95 \%$ confidence limits indicate that it is possible that no true relationship exists given the sample sizes involved.

Table 4 gives the phenotypes of the blood group systems, haptoglobin, and isoenzyme types by stage at presentation. The Kidd and Penney blood groups iv are omitted owing to small sample sizes. Table $5 \overrightarrow{\vec{H}}$ summarises the results from the previous table in the $\vec{N}$

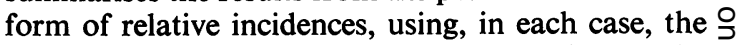
Durham control groups as a comparison. The brackets indicate results not significant at the $5 \% \rightarrow$ level of probability. The T4 stage was combined with the T3 because of small numbers. The majority of $\overrightarrow{0}$ these results are not statistically different from unity. Carcinoma in situ was not included because of the small numbers.

The acid phosphatase and adenosine deaminase systems, which showed a significantly lowered relative incidence in table 3 , give similar results at all $\stackrel{\varnothing}{\varnothing}$ the stages of presentation. The low relative incidence $\varnothing$ of phosphoglucomutase, however, is the result of a $\overrightarrow{\overrightarrow{0}}$ deficit of the 1-1 phenotype, but this is largely confined to stage 1 and 2 disease.

No particular trends are discernible in the Duffy and Kell blood group systems. A non-significant trend exists in the adenylate kinase system with a progressive deficit of the 1-1 phenotype with increasing stage. There are two other unexpected results; the haptoglobin phenotypes have a gross deficit of the 1-1 phenotypes in stage 2 disease, while there is a statistically significant excess of the 1-1 윽 esterase $\mathbf{D}$ phenotype in later stage disease.

TABLE 5 Relative incidence of phenotypes by stage at presentation of bladder cancer.

\begin{tabular}{lllll}
\hline Phenotype & Comparison & \multicolumn{3}{c}{ Stage and relative incidence } \\
\cline { 2 - 5 } & & $T 1$ & $T 2$ & $T 3 / T 4$ \\
\hline Duffy & Fyaa/ab+bb & $(0 \cdot 86) *$ & $(1 \cdot 22)$ & $(1 \cdot 23)$ \\
Kell & KK+Kk/kk & $(1 \cdot 25)$ & $(0 \cdot 64)$ & $(1 \cdot 91)$ \\
Haptoglobin & $11 / 21+22$ & $(1 \cdot 12)$ & $0 \cdot 23$ & $(1 \cdot 46)$ \\
Acid phosphatase & A+BA/B & $(0 \cdot 65)$ & $(0 \cdot 75)$ & $(0 \cdot 71)$ \\
Phosphoglucomutase & $11 / 21+22$ & $0 \cdot 59$ & $(0 \cdot 50)$ & $(1 \cdot 06)$ \\
Adenylate kinase & $11 / 21+22$ & $(1 \cdot 46)$ & $(0 \cdot 84)$ & $(0.65)$ \\
Esterase D & $11 / 21+22$ & $(1 \cdot 26)$ & $(0.91)$ & $4 \cdot 43$ \\
Adenosine deaminase & $11 / 21+22$ & $(0.45)$ & $(0.38)$ & $(0.44)$ \\
\hline
\end{tabular}

*Not significant at $95 \%$ in brackets. 


\section{Discussion}

Many of the results presented here have not previously been reported and will need confirmation in future studies. The discussion is concerned with the relationship between these genetic blood factors and aetiology. The significance of stage at diagnosis in relation to phenotypic biases is the second major theme.

There is a general point, however, to discuss before a detailed examination of the results, namely, the appropriateness of the control group. The ages of the control group are different from those of the cases, being younger by an average of 10 years. Subdivisions by age strata within cases and controls, however, revealed no statistical differences by age and it is thought unlikely that any significant bias arises from this source.

The controls originate in County Durham rather than the neighbouring area to the south, Yorkshire. There are two factors in the decision to use these particular controls. Control data, analysed at Durham, are available only from 60 hospital patients in Yorkshire. Their results have not been included in this paper, but they are of similar age to the control subjects from Durham and in no system do the results from this small number conflict with the Durham results. Secondly, no larger series for these polymorphisms exists from Yorkshire from any other source.

The biases in the relative incidence of AP, PGM, and ADA types are all new observations which, if confirmed, could be most useful in defining a high risk group susceptible to bladder cancer in the population. They must be considered in relation to our previous report on the bias to the ABO blood group $\mathrm{A}$ gene and the $\mathrm{S}$ gene of the MNSs system. ${ }^{14}$ For example, there will be relatively few people in the general population who have the A phenotype of the ABO system, the SS phenotype of the MNSs system, and the B phenotype of the AP system, perhaps about $1.5 \%$ if the systems are distributed independently, while a case group would have these three gens combinations three times more frequently.

The natural history of different cases of bladder cancer, despite broadly similar histopathological appearances, is highly unpredictable and ranges from a well defined fronded tumour which does not invade or return after treatment to a most aggressive disease which invades the bladder wall and spreads rapidly, causing death within months of diagnosis.

There are various ways in which natural histories of bladder cancer may be examined and recorded; these include a subjective assessment of 'degree of aggressiveness' of the tumour based on hospital records of cystoscopies. This was attempted in an early paper ${ }^{11}$ but is poorly reproducible. Alternatively, differential length of survival might be measured, but in the case of the present study several more years of observation would be needed to begin to examine the problem in this fashion. A third approach, which is also useful in a clinical predictive role, is to examine the depth of invasiveness of the tumour at diagnosis. One advantage of this staging procedure is that it is an internationally agreed classification. ${ }^{17}$

The carcinoma in situ lesions represent a special case with respect to this classification, however, in that they are potentially highly invasive tumours 2728 which are rare but, where recognised, are regarded as lesions needing aggressive treatment in an attempt to stop deep invasion.

As a measure of natural history, the $T$ system is imperfect but has enough advantages to be considered at length. The T1 and T2 types are a mixture of two types: aggressive lesions and the majority of slow growing lesions, which will rarely cause death. Coupled with this hypothesis are the observations that cigarette smoking is only related as a risk factor to $\mathrm{T} 1$ and $\mathrm{T} 2$ type tumours. ${ }^{29}$ However, another genetic factor, the phenotypic variants of the liver bound enzyme $\mathrm{N}$-acetyltransferase, has an excess of the slower types associated with T3, T4, and carcinoma in situ. ${ }^{30}$

These facts rather suggest that despite its imperfection the $\mathrm{T}$ types are useful in subdividing bladder cancer into two general types: the broadly invasive group and the broadly non-invasive.

Returning to the new results presented here, the fact that some gene excesses in PGM, haptoglobin, and esterase are confined to either the T1 and T2 or the T3/T4 types is a further confirmation that epidemiological differences probably exist between different $T$ types of bladder cancer.

With respect to the results, it should be remembered that multiple comparisons are inherently dangerous, as some results might be expected to be significant just by chance. A more stringent level of significance of $1 \%$ will still result in the statistically significant excess of the 1 gene in ESD and the PGM and haptoglobin results found in table 5 .

The significance of these results is not readily apparent although it is clear that the cell surface antigenic structure of cells is related to the invasiveness or otherwise of bladder tumours ${ }^{31}$ with respect to the $A B O$ blood groups, and this might also be the case with other red cell suriace markers. In addition, a person's enzymic structure is undoubtedly important in bladder carcinogenesis with respect to $\mathrm{N}$-acetyltransferase $\mathrm{e}^{30}$ and this could also be the case with regard to other enzyme systems, 
the enzymes in the red blood cell being a reflection of their presence in other tissues.

These observations and those on the $\mathrm{ABO}$ and MNSs systems ${ }^{14}$ form the basis of a general approach to the identification of high risk subgroups of the general population. Other studies have paralleled these to find risk occupations and other environmental factors. ${ }^{1516}$ It is the aim of this group of studies in genetics-epidemiology to link all aspects of tumour natural history and environmental exposure in future work with a view to disease control.

This study was financed by an award from the Special Trustees of St James's Hospital and the Department of Anthropology, University of Durham. We would like to thank Miss L Bailey and Miss T Horsfall for laboratory assistance and Miss Fiona Landells for typing the manuscript. In addition the nursing staff at all the centres concerned were invaluable in the conduct of this study; these include Sisters Greatorex and Nuttall.

\section{References}

1 Walther WW, Raeburn C, Case J. Blood groups in relation to malignant diseases. Lancet 1956;ii:970-2.

2 Speiser P. Krankheiten und Blutgruppen. Krebsarzt 1958; 13:208-18.

3 Mobilio G, Torchiana B. Considerazioni statistiche fra gli emogruppi del sistema 'ABO' e le principali malattie urologiche. Riv Anat Pat Oncol 1960;18:801-80.

4 Visconti A, Tolio A, Cava L. Correlazione fra neoplasie e gruppi sanguingni del sistema ABO. Tumori $1961 ; 47$ : 303-16.

5 Dick W, Schneider W, Brockmüller K. Über das gegensätzlicke verhalten der blutgruppen $\mathrm{A} 1$ and $\mathrm{A} 2$. Dtsch Med Wochenschr 1962;87:2567-73.

6 Muñoz-Barrata C. Blood group and disease. 8th Cong Int Soc Blood Transf Tokyo 1960. Bibliographia Haematologica 1962;13:260-6.

7 Tyagi SP, Pradhan S, Agarwal SS. Blood groups in malignant diseases. J Indian Med Assoc 1965;45:645-50.

8 Sadek AM, Guemeh N, Fahim MAS. The relationship between $\mathrm{ABO}$ blood group and gastrointestinal diseases. Alexandria Med 1965;11:119-24.

9 Ghooi AM, Kamalpuria SK, Jain PK, Tandon PL. Distribution of blood groups in cancer. Indian J Cancer 1970;7:296-305.

10 Paterson PJ. ABH secretor status in patients with bladder tumours, Urol Res 1976;4:147-50.

11 Herring DW, Cartwright RA, Williams DRR. Genetic association of transitional cell carcinoma. Br J Urol $1979 ; 51: 73-7$.

12 Mourant AE, Kopeč AC, Domaniewska-Sobczak K. Blood group and diseases. Oxford: Oxford University Press, 1978.
13 Williams DRR, Cartwright RA. The esterase D poly- $\frac{\mathbb{D}}{7}$ morphism in patients with diabetes or carcinoma of the bladder and a matched sample of non-donor controls. Ann Hum Biol 1978;5:281-4.

14 Cartwright RA, Adib R, Appleyard I, et al. ABO, MNSs and Rhesus blood groups in bladder cancer. $\mathrm{Br} J$ Urol (in press).

15 Glashan RW, Cartwright RA. Occupational bladder cancer and cigarette smoking in West Yorkshire. Br J Urol $\mathrm{Q}$ $1981 ; 53: 602-4$.

16 Cartwright RA, Adib RA, Glashan RW, Gray BK. The epidemiology of bladder cancer in West Yorkshire. A $\vec{O}$ preliminary report on non-occupational aetiologies. Carcinogenesis $1981 ; 2: 343-7$.

17 UICC. TNM classification of malignant tumours. 3rd ed. Geneva: WHO, 1978.

18 Harris H, Robson EB, Siniscalco M. Genetics of plasma protein varients. In: Wolstenholm GEW, O'Connor C, N eds. CIBA symposium: biochemistry of human genetics. i London: Churchill, 1959:151-73.

19 Hopkinson DA, Harris H. Rare phosphoglucomutase $\vec{N}$ phenotypes. Ann Hum Genet 1966;30:167-81.

20 Hopkinson DA, Harris H. Red cell acid phosphatase, 을 phosphoglucomutase and adenylate kinase. In: Biochemical methods in red cell genetics. New York: I Academic Press, 1969:337-75.

21 Rapley S, Robson EB, Harris H, Smith MS. Data on the incidence segregation and linkage relations of the adenylate kinase (AK) polymorphism. Ann Hum Genet $1967 ; 31: 237-42$.

22 Hopkinson DA, Cook PJL, Harris H. Further data on the adenosine deaminase (ADA) polymorphism and a report of a new phenotype. Ann Hum Genet 1969;32:361-7.

23 Williams DRR. Genetic and epidemiological aspects of diabetes mellitus. PhD thesis, Durham University, 1977.

24 Woolf B. On estimating the relation between blood group and disease. Ann Hum Genet 1954;19:251-3.

25 Mantel N, Haenszel W. Statistical aspects of the analysis 3 of data from retrospective studies of diseases. $J$ Natl Cancer Inst 1959;22:719-48.

26 Miettinen OS. Estimability and estimation in casereferent studies. Am J Epidemiol 1976;103:226-35.

27 Cartwright RA, Glashan RW, Gray B. Survival of transitional cell carcinoma in 2 Yorkshire centres. $\mathrm{Br} J \mathrm{O}$ Urol 1980;52:497-9.

28 Cartwright RA, Barham-Hall D. Unpublished survival data.

29 Cartwright RA, Barham-Hall D. Cigarette smoking and bladder cancer : a case-control study from West Yorkshire. Submitted for publication.

30 Cartwright RA, Glashan $\mathrm{RW}$, Rogers $\mathrm{HJ}$, et al. The role of $\mathrm{N}$-acetyltransferase phenotypes in bladder carcinogenesis. Lancet 1982 ;ii:842-6.

31 Bishop MC. Blood group antigens and bladder cancer. Br Med J 1982;284:1426-7.

Requests for reprints to $\operatorname{Dr} \mathbf{R}$ A Cartwright, Yorkshire Regional Cancer Organisation, Cookridge Hospital, Leeds LS16 6QB. 